\title{
Nutrient analysis and sensory qualities of black, red, and white rice (Oryza sativa L.) cultivars grown under different nutrient management in strongly alkaline soil
}

\author{
Ton-ogan, M. ${ }^{1}$ and D.M. Bañoc ${ }^{2 *}$ \\ ${ }^{1}$ College of Agriculture and Fisheries, Capiz State University, Pontevedra Campus, Bailan, Pontevedra, Capiz, \\ Philippines. \\ ${ }^{2}$ Department of Agronomy, Visayas State University, Visca, Baybay City, Leyte, Philippines.
}

\begin{abstract}
Appropriate nutrient management could influence the eating and grain qualities, and physicochemical properties of rice cultivars. The study aims to determine the grain yield and yield components, and nutrient content of black, red, and white rice cultivars as influenced by nutrient management under strongly alkaline soil. Evaluating the sensory qualities of different rice cultivars as influenced by nutrient management under strongly alkaline soil, and determines the suitable rice cultivar for optimum grain productivity. The study was laid out in a split-plot arranged in a Randomized Complete Block Design (RCBD) with rice cultivars as the main plot and nutrient management as the subplot. Statistical analysis revealed that black rice gave relatively higher crude fat and ash content with the same amount of nitrogen to red rice, however much lower to nitrogen, sugar, and starch content than white rice under strongly alkaline conditions. Application of pure poultry litter, inorganic fertilizer, or a combination of both does not enhance crude fat and starch content of all rice cultivar except the unfertilized plants $\left(T_{1}\right)$. Application of pure inorganic $\left(\mathrm{T}_{2}\right)$ and combined application $\left(\mathrm{T}_{4}\right)$ increased $\mathrm{N}$ and sugar than unfertilized control $\left(\mathrm{T}_{1}\right)$. Texture and general acceptability were significantly affected by rice cultivars tested where red and black rice are comparably perceived as "like very much" than white rice, which is perceived to be "like slightly." No significant differences in other physical attributes such as color, aroma, and taste. All physical characteristics of sensory analysis were not influenced by nutrient management applied.
\end{abstract}

Keywords: Alkaline soil; eating quality; nutrient content; rice cultivars; sensory evaluation.

\section{Introduction}

Rice (Oryza sativa L.) is a staple crop of the majority of the human populace worldwide. This crop is mainly grown in the lowlands, especially under irrigated lowland ecosystems. Rice plants can grow best under a soil $\mathrm{pH}$ of 5.5 since soil $\mathrm{pH}$ affects many physical, chemical, and biological properties of the soil, which in turn also affect the growth of lowland rice $(\mathrm{Yu}$, 1991). However, rice production nowadays is greatly affected by some reasons. One of those reasons is low productivity due to soil alkalinity that hampered its growth and development. One

\footnotetext{
*Corresponding author: Dionesio M. Bañoc Email: dionesio.banoc@vsu.edu.ph Received: November 1, 2021; Accepted: December 12, 2021; Published online: January 1, 2022 CP Published by South Valley University.

This is an open access article licensed under c(i) (2)
}

of the most noticeable constraints in alkaline soils is generally the non-availability of iron. There are instances that the non-solubility of iron is present in abundant quantities and would therefore be made unavailable for plant utilization. The availability of phosphorus, including micronutrients; zinc, copper, and manganese, is reduced at high $\mathrm{pH}$ values. The problem can be more harmful by climate change; thus, planting alkaline-tolerant rice varieties and proper nutrient management must be used and managed more efficiently. There are potential rice varieties that might tolerate the presence of soil alkalinity. Red rice, black rice, and white rice are those selected rice cultivars that might solve low productivity in alkaline soils. In as much as appropriate nutrient management strategies through an 
integrated approach might also be a useful alternative for enhancing rice growth and development under such conditions. Thus, proper nutrient management and suitable rice cultivars may improve crop productivity in these areas. Applying poultry litter and supplemental application with inorganic fertilizer can be an option for conventional inorganic rice production. This organic manure may provide nutrient elements that are limited to inherently alkaline soil.

The studies have shown that agricultural practices can influence the nutrient composition of rice grains. Results found that soil nitrogen, solar radiation, maturity, and integrated nutrient management like poultry litter and other inorganic fertilizers influence chemical composition or protein content in rice (Juliano and Bechtel, 1985). It also improves rice grain quality in terms of chemical composition, cooking quality, and a high score of sensory evaluation (Sangeetha et al., 2013)

Application of poultry litter and its combination with inorganic fertilizer may provide nutrient elements hampered under inherently alkaline soil, which can be an option for conventional inorganic rice production. With the adoption of appropriate nutrient management and rice cultivar in rice production under alkaline soils, achieving good eating and grain quality of rice as the primary concern of every consumer can be made possible. Hence, this study aimed to determine the grain yield and yield components, and nutrient content of black, red, and white rice cultivars as influenced by nutrient management under strongly alkaline soil. Evaluate the sensory qualities of black, red, and white rice cultivars as influenced by nutrient management under strongly alkaline soil; determine the suitable rice cultivar for optimum grain productivity under strongly alkaline soil.

\section{Materials and Methods}

\subsection{The study site and land preparation}

The study was conducted in a lowland rice field in Brgy. Pomponan, Baybay City, Leyte, the Philippines from December 21, 2018, until April 24, 2019, with Himayangan clay loam soil series (Armecin et al., 2011), which is inherently alkaline with a soil $\mathrm{pH}$ of 7.89 . The specific experimental site has a geographical coordinate of $10^{\circ} 41^{\prime} \mathrm{N}$ and $124^{\circ} 48^{\prime} \mathrm{E}$ (Maplandia.com. 2021) under type four climate wherein rainfall is evenly distributed throughout the year (Lantican, 2001; Kintanar, 1984). An area of $699.2 \mathrm{~m}^{2}$ was prepared using a two-wheeled hand tractor, which three times tractor operations were done until the area was ready for transplanting.

\subsection{Soil sampling}

Before transplanting, soil samples were randomly collected in the experimental area. The samples were submitted to analyze soil $\mathrm{pH}$ adopting the Potentiometric Method at a 1:1 soil-water ratio (PCARR, 1980). The total N through Kjeldahl Method (Nelson and Sommers, 1982), available P through Olsen Method (Olsen et al., 1954), exchangeable K through extraction method using atomic absorption spectrophotometry (ISRIC, 1995). The soil $\mathrm{pH}$, total $\mathrm{N}$, available $\mathrm{P}$, exchangeable $\mathrm{K}$, available $\mathrm{Na}, \mathrm{Mg}, \mathrm{Mn} \mathrm{Ca}, \mathrm{Fe}$, and $\mathrm{Zn}$ was analyzed at the Central Analytical Service Laboratory (CASL), PhilRootcrops, Visayas State University (VSU), Visca, Baybay City, Leyte, Philippines. Another set of soil samples were collected separately from each treatment plot right after harvesting. Samples collected per plot were composited and analyzed for the same soil parameters mentioned above.

\subsection{Experimental design, layout, and treatments}

The experiment was laid out in a split-plot arranged in a Randomized Complete Block Design (RCBD) with three replications. Rice cultivar was designated as the main plot and the different nutrient management as the subplot. Each subplot measured $4 \mathrm{~m} \times 3 \mathrm{~m}$ with 15 rows per plot. Replication and treatment plots were separated by two-meter and $0.70 \mathrm{~m}$ alleyways, respectively, to prevent contamination of treatments and facilitate farm operations and data gathering. The different main plot treatments (Rice cultivars) were $\mathrm{M}_{1}$ - Black rice (Ballatinao cultivar), $\mathrm{M}_{2}$ - Red rice (Red 64 cultivar), and $\mathrm{M}_{3}$ - White rice (NSIC Rc216). 
The subplot treatments relative to nutrient management were no fertilizer application control $\left(\mathrm{T}_{1}\right), 120-60-60 \mathrm{~kg} \mathrm{ha}^{-1} \mathrm{~N}, \mathrm{P}_{2} \mathrm{O}_{5}, \mathrm{~K}_{2} \mathrm{O}$ $\left(\mathrm{T}_{2}\right), 5 \mathrm{t} \mathrm{ha}^{-1}$ poultry litter $\left(\mathrm{T}_{3}\right)$, and $2.5 \mathrm{t} \mathrm{ha}^{-1}$ poultry litter + 60-30-30 $\mathrm{kg} \mathrm{ha}^{-1} \mathrm{~N}, \mathrm{P}_{2} \mathrm{O}_{5}, \mathrm{~K}_{2} \mathrm{O}$ $\left(\mathrm{T}_{4}\right)$.

\subsection{Rice cultivars used}

White rice (NSIC RC216 - Tubigan 17), an inbred lowland rice variety is a good source of energy and various nutrients and minerals preferred by most people (DA-PhilRice, 2021). However, it may cause humans to develop diabetes mellitus and other disorders due to immoderate consumption. Both black (Ballatinao cultivar) and red rice (Red 64 cultivar) types were known worldwide as the best substitute for white rice, mainly consumed for their additional health benefits. It helps prevent diabetes mellitus, improves digestive health, and had anticancer effects due to anthocyanin and tannin pigments on its pericarp (Kushwaha, 2016). Both rice cultivars also have much higher fiber than white rice, found to be suitable for people with cardiovascular diseases as it can significantly lower blood cholesterol.

\subsection{Crop establishment and cultural management}

Twenty-day-old rice seedlings were uniformly transplanted in all varieties at one to two seedlings per hill at a planting distance of $20 \mathrm{~cm} \times 20 \mathrm{~cm}$ between hills and between rows. Replanting was done seven days after transplanting (DAT), while rotary weeding was manipulated at 15 DAT. After that, hand weeding was done at 25-30 DAT, while spot weeding to remove weeds around each hill was also undertaken. For the full inorganic fertilizer treatment, complete fertilizers (14-14-14) and urea (46-0-0) were applied to satisfy the fertilizer recommendation of 120-60-60 $\mathrm{kg} \mathrm{ha}^{-1}$ $\mathrm{N}, \mathrm{P}_{2} \mathrm{O}_{5}, \mathrm{~K}_{2} \mathrm{O}$ ha $^{-1}$. Complete fertilizer (14-1414) amounting to $514.28 \mathrm{~g}$ treatment plot $^{-1}$ applied ten days after transplanting. The remaining $\mathrm{N}$ requirement was satisfied by broadcasting urea at $156.52 \mathrm{~g}$ treatment plot $^{-1}$ during the panicle initiation stage. For the combined application of inorganic and organic fertilizer treatment $\left(\mathrm{T}_{4}\right)$ and purely applied poultry litter $\left(\mathrm{T}_{3}\right)$, poultry litter was used and applied seven days before transplanting. The inorganic fertilizer for $\mathrm{T}_{4}$ was satisfied using complete fertilizer at $257.15 \mathrm{~g} \mathrm{plot}^{-1}$ and applied through broadcast method at ten DAT. The remaining $\mathrm{N}$ requirement was met by broadcasting urea at $78.26 \mathrm{~g} \mathrm{plot}^{-1}$ at the panicle initiation stage. For water management, intermittent irrigation was imposed from panicle initiation until two weeks before harvest to facilitate harvesting.

Handpicking of Golden Apple Snail-GAS (Pomacea canaliculata L.) was done a day before transplanting and were followed after another two days. Then, twenty-five grams of methomyl insecticide was sprayed to control insect pests like rice ear bug (Leptocorisa oratoria) and case worm (Parapoynx stagnalis) during vegetative to reproductive growth stages. Rat baiting using slow acting rodenticide was done one week before transplanting as a preventive measure and repeated during panicle initiation and heading stage.

\subsection{Harvest and postharvest management}

Plants within the harvestable area $\left(8.32 \mathrm{~m}^{2}\right)$ were harvested when $85 \%$ of the grains in each treatment plot's panicles were ripened. The panicles within the harvestable area were cut at the base using a sharp sickle. The sample panicles were threshed, dried for three days to attain $14 \%$ moisture content, and were cleaned before gathering all the necessary data.

\subsection{Seed preparation for nutrient analysis and sensory evaluation}

The $500 \mathrm{~g}$ composite sample grains from each treatment were oven-dried at $70^{\circ} \mathrm{C}$ for 72 hours as part of nutrient analysis. The sample grains were ground into fine particles and submitted to the Central Analytical Services Laboratory (CASL) at PhilRootcrops, VSU, Visca, Baybay City, Leyte, Philippines; for the analysis of the total nitrogen, ash, fiber, crude fat, sugar, and starch.

The sensory attributes of cooked rice from different treatments were evaluated using quality description combined with the nine- 
point Hedonic scale. The milled sample grains from each treatment plot weighing $500 \mathrm{~g}$ were boiled for 40 to 45 minutes. The cooked rice was submitted to evaluate the sensory quality and acceptance tests to the Department of Food Science and Technology, VSU, Visca, Baybay City, Leyte, Philippines. Six trained panelists evaluated each sample relative to color, aroma, taste, texture, flavour, and general acceptability. The sensory evaluation outputs were subjected to a two-way analysis of variance using the computer software Statistical Tools for Agricultural Research (STAR). The mean comparison was done using the Least Significant Difference (LSD) test.

\subsection{Data gathered}

The data gathered were mainly focused on the number of productive tiller hill ${ }^{-1}$, grain weight hill-1 ${ }^{-1}$ and grain yield $\left(\mathrm{tha}^{-1}\right)$ and on the nutrient analysis of rice grains. The nutrient analysis gathered were nitrogen, ash, fiber, crude fat, sugar, and starch. However, rice grains' sensory quality and acceptance tests include color, aroma, taste, texture, flavour, and general acceptability evaluation were also taken into consideration in data gathering.

\section{Results and discussion}

\subsection{Soil chemical properties}

The initial soil analysis result showed that the soil had a pH of 7.89 with $2.15 \%$ organic matter, $0.15 \%$ total $\mathrm{N}, 9.48 \mathrm{mg} \mathrm{kg}^{-1}$ available

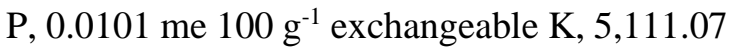
me $100 \mathrm{~g}^{-1} \mathrm{Ca}, 342.66 \mathrm{me} 100 \mathrm{~g}^{-1} \mathrm{Mg}$, a trace amount of Na, $1.58 \mathrm{mg} \mathrm{kg}^{-1} \mathrm{Fe}, 8.04 \mathrm{mg} \mathrm{kg}^{-1}$ $\mathrm{Mn}, 3.24 \mathrm{mg} \mathrm{kg}^{-1} \mathrm{Cu}$, and $1.46 \mathrm{mg} \mathrm{kg}^{-1} \mathrm{Zn}$ (Table 1). These imply that the soil is strongly alkaline, with low amounts of organic matter, total $\mathrm{N}$, and available $\mathrm{P}$, very low amount of exchangeable $\mathrm{K}$, low amounts of $\mathrm{Fe}$ and $\mathrm{Zn}$, a moderate amount of $\mathrm{Cu}$, a high amount of $\mathrm{Mn}$, and very high amounts of $\mathrm{Ca}$ and $\mathrm{Mg}$ (Landon, 1991). After harvest, the final analysis results revealed a slight decrease in soil $\mathrm{pH}$ from a strongly alkaline to a moderately alkaline level. However, a slight increase in $\mathrm{OM}$, total $\mathrm{N}$, and exchangeable $\mathrm{K}$ was observed, especially in treatment plots applied with $5 \mathrm{t} \mathrm{ha}^{-1}$ poultry litter $\left(\mathrm{T}_{3}\right)$, mainly attributed to the high contents of nutrient elements poultry litter applied (Table 1). The result aligns with Hamed et al. (2011) and Amanullah et al. (2007) that poultry manure serves as a source of $\mathrm{N}$ and $\mathrm{P}$ and provides nutrients such as $\mathrm{Ca} \mathrm{Mg}, \mathrm{S}$, and $\mathrm{Fe}$. A decrease in $\mathrm{Ca}, \mathrm{Mn}, \mathrm{Zn}$, and $\mathrm{P}$ 's available amount were due to plants' utilization of the said elements, especially those without fertilizer. On the other hand, the different subplot treatments increased to $\mathrm{Mg}, \mathrm{Fe}$, and $\mathrm{Cu}$ while the amount of $\mathrm{Ca}$ decreases indicating the decline in $\mathrm{pH}$, especially in those plots applied with pure inorganic fertilizer at the rate of 12060-60 kg ha- ${ }^{-1} \mathrm{~N}, \mathrm{P}_{2} \mathrm{O}_{5}, \mathrm{~K}_{2} \mathrm{O}\left(\mathrm{T}_{2}\right)$.

\subsection{Number of productive tillers hill $^{-1}$, grain weight (g) hill ${ }^{-1}$, and grain yield (t hat $\left.{ }^{-1}\right)$ as influenced by nutrient management under strongly alkaline soil}

Statistical analysis showed that the number of productive tillers hill-1, grain weight hill $^{-1}$, and grain yield $\left(\mathrm{t} \mathrm{ha}^{-1}\right)$ were significantly affected by nutrient management adopted (Figures 1a, 1b 1c). Regardless of rice cultivar, plants applied with $2.5 \mathrm{t} \mathrm{ha}^{-1}$ poultry litter +60 30-30 kg ha- ${ }^{-1} \mathrm{~N}, \mathrm{P}_{2} \mathrm{O}_{5}, \mathrm{~K}_{2} \mathrm{O}\left(\mathrm{T}_{4}\right)$ significantly produced more productive tillers (11.43) comparable to those plants applied with 12060-60 kg ha- ${ }^{-1} \mathrm{~N}, \mathrm{P}_{2} \mathrm{O}_{5}, \mathrm{~K}_{2} \mathrm{O}\left(\mathrm{T}_{2}\right)$ (Fig. 1a). Rice plants applied with pure poultry litter at $5 \mathrm{t} \mathrm{ha}^{-1}$ $\left(T_{3}\right)$ and unfertilized control $\left(T_{1}\right)$ had few numbers of productive tillers. Thereby, the combined application of poultry litter and inorganic fertilizer resulted in a significant increase in rice tillers due to its synergistic effect of increasing levels of nitrogen and phosphorus in the soil, which in turn promotes tillering (Belefant, 2007). 
Table 1. Soil test results before planting and after harvest of black, red, and white rice (Oryza sativa L.) cultivars as influenced by nutrient management under strongly alkaline soil

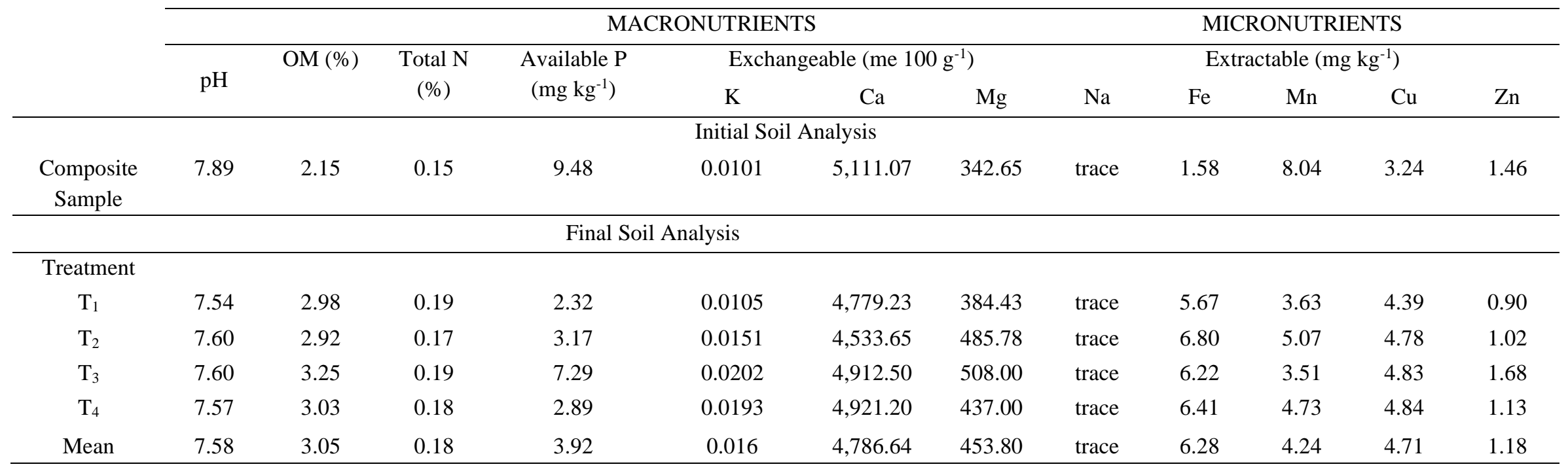

Legend:

$\mathrm{T}_{1}=$ No fertilizer application (control)

$\mathrm{T}_{2}=120-60-60 \mathrm{~kg} \mathrm{ha}^{-1} \mathrm{~N}, \mathrm{P}_{2} \mathrm{O}_{5}, \mathrm{~K}_{2} \mathrm{O}$

$\mathrm{T}_{3}=5 \mathrm{t} \mathrm{ha}^{-1}$ poultry litter

$\mathrm{T}_{4}=2.5 \mathrm{tha}^{-1}$ poultry litter $+60-30-30 \mathrm{~kg} \mathrm{ha}^{-1} \mathrm{~N}, \mathrm{P}_{2} \mathrm{O}_{5}, \mathrm{~K}_{2} \mathrm{O}$ 

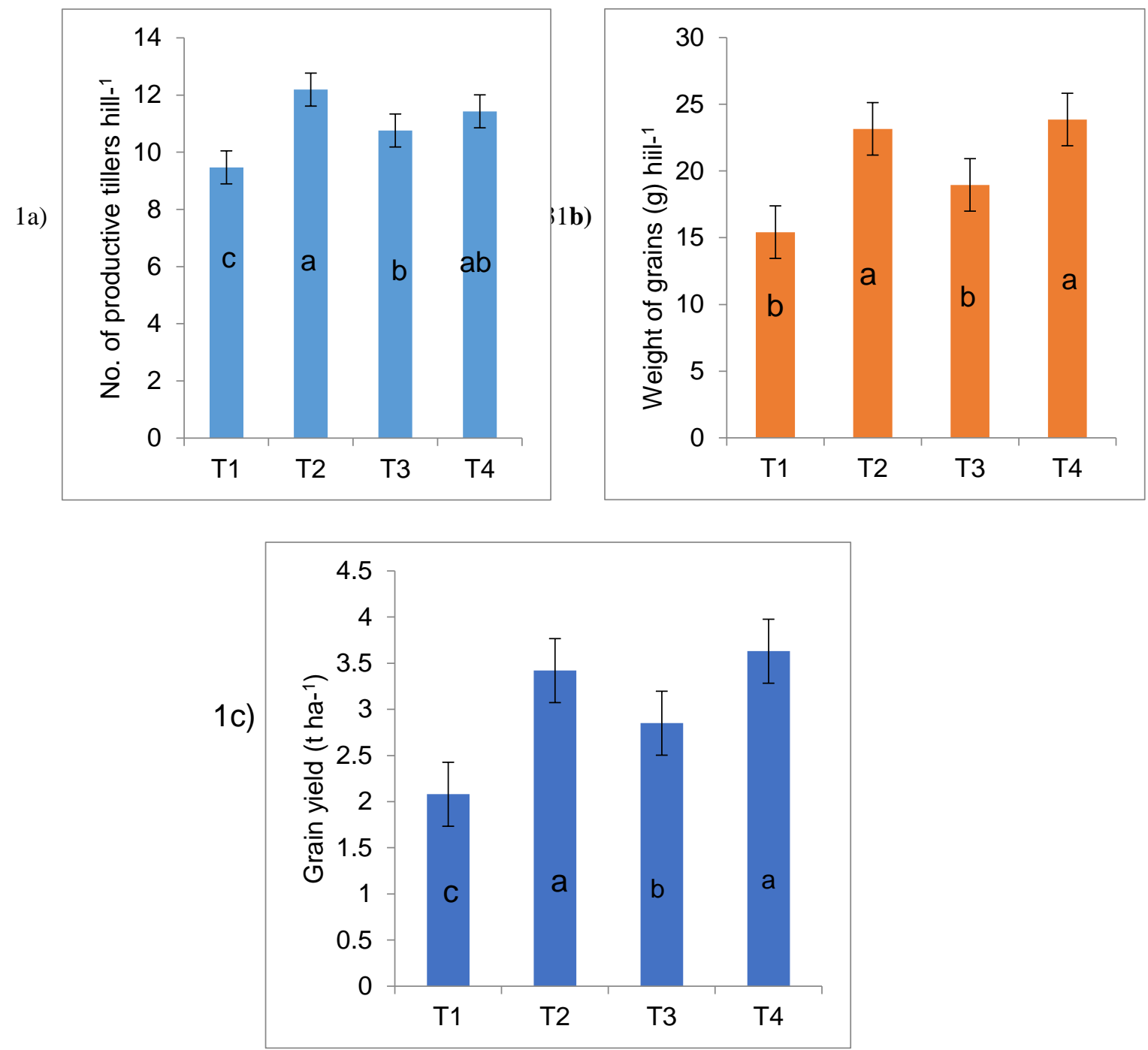

Treatment means with the same and without letter designations are not significantly different at 0.05 LSD.

$$
\begin{aligned}
& \text { Legend: } \\
& \mathrm{T}_{1}=\text { No fertilizer application (control) } \\
& \mathrm{T}_{2}=120-60-60 \mathrm{~kg} \mathrm{ha}^{-1} \mathrm{~N}, \mathrm{P}_{2} \mathrm{O}_{5}, \mathrm{~K}_{2} \mathrm{O} \\
& \mathrm{T}_{3}=5 \mathrm{tha}^{-1} \text { poultry litter } \\
& \mathrm{T}_{4}=2.5 \mathrm{tha}^{-1} \text { poultry litter }+60-30-30 \mathrm{~kg} \mathrm{ha}^{-1} \mathrm{~N}, \mathrm{P}_{2} \mathrm{O}_{5}, \mathrm{~K}_{2} \mathrm{O}
\end{aligned}
$$

Figure. 1a, 1b, 1c. Number of productive tillers, the weight of grains $(\mathrm{g}) \mathrm{hill}^{-1}$, and grain yield $\left(\mathrm{t} \mathrm{ha}^{-1}\right)$ of rice (Oryza sativa L.) cultivars as influenced by nutrient management under strongly alkaline soil 
For the weight of grains per hill (Fig. 1b) and grain yield $\left(\mathrm{t} \mathrm{ha}^{-1}\right)$ (Fig. 1c), plants applied with $2.5 \mathrm{t} \mathrm{ha}^{-1}$ poultry litter $+60-30-30 \mathrm{~kg} \mathrm{ha}^{-1} \mathrm{~N}$, $\mathrm{P}_{2} \mathrm{O}_{5}, \mathrm{~K}_{2} \mathrm{O}\left(\mathrm{T}_{4}\right)$ significantly achieved heavier grains hill ${ }^{-1}$ of $23.86 \mathrm{~g}$ compared to those plants applied with pure poultry litter at $5 \mathrm{t} \mathrm{ha}^{-1}\left(\mathrm{~T}_{3}\right)$ and unfertilized plants $\left(\mathrm{T}_{1}\right)$ (Fig. 1b). However, $\mathrm{T}_{4}$ plants were comparable to those plants that received pure inorganic fertilizer $\left(\mathrm{T}_{2}\right)$. A similar trend was also noted to its grain yield wherein rice plants applied with $2.5 \mathrm{t} \mathrm{ha}^{-1}$ poultry litter $+60-30-30 \mathrm{~kg} \mathrm{ha}^{-1} \mathrm{~N}, \mathrm{P}_{2} \mathrm{O}_{5}, \mathrm{~K}_{2} \mathrm{O}\left(\mathrm{T}_{4}\right)$ significantly obtained higher grain yield $(3.63 \mathrm{t}$ $\left.\mathrm{ha}^{-1}\right)$ than those plants under $\mathrm{T}_{3}\left(2.85 \mathrm{tha}^{-1}\right)$ and unfertilized control $\left(\mathrm{T}_{1}\right)$ with only $2.08 \mathrm{t} \mathrm{ha}^{-1}$ but comparable to those plants that received pure inorganic fertilizer at the rate of 120-60-60 kg $\mathrm{ha}^{-1} \mathrm{~N}, \mathrm{P}_{2} \mathrm{O}_{5}, \mathrm{~K}_{2} \mathrm{O}\left(\mathrm{T}_{2}\right)$ with $3.42 \mathrm{tha}^{-1}$. This result corroborates with the findings of Hasanuzzaman et al. (2010) that application of poultry litter at $4 \mathrm{tha}^{-1}+50 \%$ of recommended NPK produced the highest grain yield of rice.

\subsection{Nutrient analysis of rice grains}

The awareness of rice's nutritive value and health benefits is a vital undertaking to increase rice consumption in the human daily diet (Verma and Srivastav, 2017). The result of grain analysis of lowland rice as influenced by rice cultivar and nutrient management under strongly alkaline soil was reflected in Table 2.

The results showed that under alkaline conditions, red rice and black rice gave relatively higher crude fat and ash content. Red rice gave the same amount of nitrogen as black rice, while white rice obtained relatively higher nitrogen, sugar, and starch content. The high nitrogen content can be attributed to the amount of nitrogen present in the soil, as amended by different nutrient management. For pure poultry litter application, purely inorganic fertilizer and combined organic and inorganic application did not enhance the crude fat and starch content of all rice cultivars except the unfertilized plants $\left(T_{1}\right)$, which contains a higher amount of crude fat and starch. The result is associated with the high amount of sugar and carbohydrates as a good source of energy and the primary source of a range of nutrients for the human diet (Weininger et al., 2018). Relative to plants under $\mathrm{T}_{4}$, application of $2.5 \mathrm{t}$ ha ${ }^{-1}$ poultry litter $+60-30-30 \mathrm{~kg} \mathrm{ha}^{-1} \mathrm{~N}, \mathrm{P}_{2} \mathrm{O}_{5}$, $\mathrm{K}_{2} \mathrm{O}$ higher value in nitrogen and sugar content of rice. In terms of ash content, plants applied with 120-60-60 kg ha-1 $\mathrm{N}, \mathrm{P}_{2} \mathrm{O}_{5} \mathrm{~K}_{2} \mathrm{O}\left(\mathrm{T}_{2}\right)$ contained a relatively higher amount of ash of $0.199 \%$.

Table 2. Nutrient content on grains of lowland rice (Oryza sativa L.) as influenced by rice cultivar and nutrient management under strongly alkaline soil

\begin{tabular}{|c|c|c|c|c|c|}
\hline \multirow[b]{2}{*}{ Treatment } & \multicolumn{5}{|c|}{ TOTAL (\%) } \\
\hline & Crude Fat & Ash & Nitrogen & Sugar & Starch \\
\hline \multicolumn{6}{|l|}{ Rice cultivars } \\
\hline $\mathrm{M}_{1}=$ Black rice & 0.610 & 0.199 & 0.933 & 0.955 & 64.588 \\
\hline $\mathrm{M}_{2}=$ Red rice & 0.593 & 0.124 & 0.933 & 0.655 & 61.938 \\
\hline $\mathrm{M}_{3}=$ White rice & 0.491 & 0.162 & 0.968 & 1.278 & 65.978 \\
\hline Mean & 0.560 & 0.160 & 0.940 & 0.960 & 64.170 \\
\hline \multicolumn{6}{|l|}{ Nutrient management } \\
\hline $\mathrm{T}_{1}$-No fertilizer application (control) & 0.737 & 0.149 & 0.879 & 0.761 & 67.452 \\
\hline $\mathrm{T}_{2}-120-60-60 \mathrm{~kg} \mathrm{ha}^{-1} \mathrm{~N}, \mathrm{P}_{2} \mathrm{O}_{5}, \mathrm{~K}_{2} \mathrm{O}$ & 0.342 & 0.199 & 1.162 & 1.001 & 65.132 \\
\hline $\mathrm{T}_{3}-5 \mathrm{t} \mathrm{ha}^{-1}$ poultry litter & 0.609 & 0.166 & 0.527 & 0.723 & 61.561 \\
\hline $\begin{array}{l}\mathrm{T}_{4}-2.5 \mathrm{t} \mathrm{ha}^{-1} \text { poultry litter } \\
\quad+60-30-30 \mathrm{~kg} \mathrm{ha}^{-1} \mathrm{~N}, \mathrm{P}_{2} \mathrm{O}_{5}, \mathrm{~K}_{2} \mathrm{O}\end{array}$ & 0.566 & 0.132 & 1.211 & 1.365 & 62.526 \\
\hline Mean & 0.56 & 0.16 & 0.94 & 0.96 & 64.17 \\
\hline
\end{tabular}

Means in a column with a similar letter and no letter designation are not significantly different based on a 5\% level of significance in (LSD). 


\subsection{Sensory analysis}

The texture is an essential attribute of food acceptance by consumers (Meullenet et al., 2000). Sensory analysis of black, red, and white rice cultivars as influenced by nutrient management under alkaline soil was observed (Table 3). The sensory analysis result revealed that texture and general acceptability were significantly affected by the different rice cultivars tested, but no significant differences in other physical attributes such as color, aroma, and taste. However, all physical characteristics of sensory analysis were not influenced by nutrient management applied. Red and black rice cultivars achieved significantly higher texture with 7.56 and 7.26, respectively, while remarkably higher general acceptability for red rice (7.10) and black rice (6.96) when compared with white rice with only 6.15 .

Red and black rice are comparably perceived as " like very much " to white rice, which is perceived as " like slightly." (Table 4). The same trend was noted for general acceptability wherein red, and black rice was consistently perceived as "like very much" comparing white rice, which was perceived as " like slightly."]

Table 3. Sensory analysis of lowland rice (Oryza sativa L.) as influenced by rice cultivar and nutrient management under strongly alkaline soil

\begin{tabular}{|c|c|c|c|c|c|}
\hline Rice cultivars & Color & Aroma & Taste & Texture & $\begin{array}{c}\text { General } \\
\text { acceptability }\end{array}$ \\
\hline $\mathrm{M}_{1}=$ Black rice & 6.26 & 6.28 & 6.01 & $7.20^{\mathrm{a}}$ & $6.96^{\mathrm{a}}$ \\
\hline $\mathrm{M}_{2}=$ Red rice & 6.19 & 5.91 & 6.09 & $7.56^{\mathrm{a}}$ & $7.10^{\mathrm{a}}$ \\
\hline $\mathrm{M}_{3}=$ White rice & 6.18 & 6.08 & 6.00 & $5.94^{\mathrm{b}}$ & $6.15^{\mathrm{b}}$ \\
\hline \multicolumn{6}{|l|}{ Nutrient management } \\
\hline $\mathrm{T}_{1}$-No fertilizer application (control) & 6.80 & 6.77 & 6.50 & 6.92 & 6.85 \\
\hline $\mathrm{T}_{2}-120-60-60 \mathrm{~kg} \mathrm{ha}^{-1} \mathrm{~N}, \mathrm{P}_{2} \mathrm{O}_{5}, \mathrm{~K}_{2} \mathrm{O}$ & 5.64 & 5.63 & 5.53 & 5.93 & 5.75 \\
\hline $\mathrm{T}_{3}-5 \mathrm{t} \mathrm{ha}^{-1}$ poultry litter & 5.82 & 5.57 & 5.60 & 5.86 & 5.72 \\
\hline $\mathrm{T}_{4}-2.5 \mathrm{t}_{\text {ha }}{ }^{-1}$ poultry litte $+60-30-30 \mathrm{~kg} \mathrm{ha}^{-1} \mathrm{~N}, \mathrm{P}_{2} \mathrm{O}_{5}, \mathrm{~K}_{2} \mathrm{O}$ & 5.91 & 5.52 & 5.62 & 5.91 & 5.67 \\
\hline C.V. (a)\% & 9.48 & 4.93 & 7.91 & 4.43 & 4.21 \\
\hline C.V. (b)\% & 6.35 & 4.53 & 4.53 & 2.98 & 1.84 \\
\hline
\end{tabular}

Means in a column with a similar letter and no letter designation are not significantly different based on a $5 \%$ level of significance in (LSD).

Table 4. Sensory evaluation acceptability level test of lowland rice (Oryza sativa L.) as influenced by rice cultivar and nutrient management under strongly alkaline soil

\begin{tabular}{llccl}
\hline \multicolumn{1}{c}{ Color } & \multicolumn{1}{c}{ Aroma } & Taste & \multicolumn{1}{c}{ Texture } & \multicolumn{1}{c}{ General Acceptability } \\
\hline 1-Slightly & 0- no perceptible aroma & 0- no & 1-(cheese) & 1- dislike extremely \\
Black/Red/White & 1- slightly perceptible & sweetness & extremely soft & 2-dislike very much \\
2-Moderately & aroma & 1- slightly & 2-(egg white) soft & 3-dislike moderately \\
Black/Red/White & 2- moderately perceptible & sweet & 3-(sausage) just & 4- dislike slightly \\
3- Intense & aroma & 2- moderately & right & 5- neither like nor dislike \\
Black/Red/White & 3-very perceptible aroma & sweet & 4- (peanuts) slightly & 6- like slightly \\
& 4-extremely perceptible & 3- very sweet & hard & 7- like very much \\
& aroma & 4- extremely & & 8-like very much \\
& & sweet & & 9- like extremely \\
\hline
\end{tabular}


This study conformed with the findings of Juliano et al. (1965) and Lorieux et al. (1996), which revealed that genetic variability, environment, and cultural practices affect the texture of the cooked rice. However, this undertaking contradicts Champagne et al. (2007) findings that nutrient management can affect rice grain and physicochemical characteristics.

The result indicated that rice cultivars have profound variation in terms of texture and general acceptability. The product supports Srisawas and Jindal's (2007) findings that acceptability scores were strongly correlated with cooked rice's textural properties. Pratiwi and Purwestri (2017) mentioned that variations in varieties might have implications in understanding various rice phenotypes and their potential uses as a functional food.

\section{Conclusion}

Based on the results obtained, red and black rice cultivars achieve a higher amount of crude fat, and ash, while white rice receives a higher amount of percent nitrogen, sugar, and starch. Regarding rice cultivars, fertilizer application increases the amount of percent nitrogen and starch of lowland rice under strongly alkaline soil. Red and black rice cultivars obtained good eating quality in terms of texture and general acceptability than that of white rice.

\section{Recommendation}

Black rice recommends massive planting due to its significantly higher grain yield (3.26 $\mathrm{t} \mathrm{ha}^{-1}$ ), good eating quality regarding texture and general acceptability, and high nutritional content (crude fat and ash content) when applied with combined application of poultry litter + 60-30-30 kg ha-1 $\mathrm{N}, \mathrm{P}_{2} \mathrm{O}_{5}, \mathrm{~K}_{2} \mathrm{O}\left(\mathrm{T}_{4}\right)$.

\section{Acknowledgment}

The authors express thanks and gratitude to the Department of Science and Technology (DOST) - Accelerated Science and Technology Human Resource Development Program (ASTHRDP) through the DOST-ASTHRDP Project Leader's full support Dr. Victor B. Asio, for providing financial support in the conduct of this research undertaking.

\section{References}

Amanullah, M.M., Somasundaran, E., Vaiyapuri, K., Sathyamoorthi, K. (2007). 'Poultry manure to crops', A review. Agricultural Reviews. 28(3), pp. $216-222$.

Armecin, R.B., Cosico, W.C., Badayos, R.B. (2011). 'Characterization of the different abaca-based agro-ecosystems in Leyte, Philippines', Journal of Natural Fibers, $8(2)$, pp. $111-125$.

Belefant, M.H. (2007). 'Poultry litter induces tillering in rice. Journal of Sustainable Agriculture. 31(1), pp. 151 - 160.

Champagne, E.T., Bett-Garber, K.L., Grimm, C.C., Mcclung, A.M. (2007). 'Effects of organic fertility management on physicochemical properties and sensory quality of diverse rice cultivars', Cereal Chemistry, 84(4), pp. $320-327$.

Juliano, B.O., Onate, L.U., Del Mundo, A.M. (1965). 'Relation of starch composition, protein content, and gelatinization temperature to cooking and eating milled rice qualities', Food Technology, 19, pp. $1006-1011$.

DA-PhilRice. (2021). 'Department of Agriculture - The Philippine Rice Research Institute', www.pinoyrice.com/rice-varieties/.

Hamed, M.H., El-Desoky, M.A., Faragallah, M.A., Usman, A.R. (2011). 'Effect of organic amendments on soil chemical properties and potassium availability to sorghum plants grown on calcareous sandy soil', Soils and Water Sci. Dept., Fac. Agric., Al-Azhar Univ., Assuit, Egypt. 15 (1).

Hasanuzzaman, M., Ahamed, K.U., Rahmatullah, M., Khater, N., Nahar, K., 
Rahman, M.L. (2010). 'Plant growth characters and productivity of wetland rice (Oryza sativa L.) as affected by the application of different manures', Emirates Journal of Food and Agriculture, pp. 46-58.

International Soil Reference and Information Center (ISRIC) (1995). 'Procedures for Soil Analysis' (L.P. Van Reuwijk, Editor) Wageningen. The Netherlands, pp.106.

Juliano, B.O., Bechtel, D.B. (1985). 'The rice grain and its gross composition', Rice. B. O. Juliano (Ed.), Rice Chemistry and Technology (2nd edition), American Association of Cereal Chemistry, Inc. St. Paul, MN (1985), pp. 17 - 57.

Kintanar, R.L. (1984). 'Climate of the Philippines'. PAGASA.

Kushwaha, U.K.S. (2016). 'Black Rice', Research, History, and Development. Springer, pp. $1-19$.

Landon, J.R. (1991). 'Booker Tropical Soil Manual. A handbook for soil survey and Agricultural Land Evaluation in the Tropics and Subtropics', Longman Science and Technical John Wiley and Sons, Inc. 605 third Avenue, New York, NY 10158, pp. 474.

Lantican, R.M. (2001). 'The Science and Practice of Crop Production. College, Los Baňos, Laguna, Phils.: SEAMEO SEARCA and UPLB, pp. 330.

Lorieux, M., Petrov, M., Huang, N., Guiderdoni, E., Ghesquière, A. (1996). 'The aroma in rice: genetic analysis of a quantitative trait', Theoretical and Applied Genetics, 93(7), pp. 1145 1151.

Maplandia.com. (2021). 'Google maps world gazetteer',Maplandia.com/Philippines/ Region-8/Southern-Leyte/Saint-
Bernard/BaybayCity/Ormoc City/JavierLeyte/.

Nelson, D.W., Sommers, L.E. (1982). 'Total Carbon, Organic Carbon and Organic Matter'. In-Page, A. L. (editor): Methods of Soil Analysis (2. edit.). Part II. Chemical and Microbiological Properties. Amer. Soc. Agron. Inc. and Soil Sci. Soc. Amer. Madison Wisconsin, pp. 539-594.

Olsen, S.R., Cole, C.V., Watanabe, F.S., Dean L.A. (1954). 'Estimation of available phosphorus in soils by extraction with NaHCO3', USDA Cir.939. The U.S.A. Washington D.C.

PCARR. (1980). 'A standard method of analysis for soil, plant tissue water, and fertilizer', Los Baňos (Laguna): Farm, Resource, and Systems Research Division, Philippine Council for Agriculture and Research. pp. 194.

Pratiwi, R., Purwestri, Y.A. (2017). 'Black rice as a functional food in Indonesia', Functional Foods in Health and Disease. 7(3), pp. $182-194$.

Meullenet, J.F., Champagne, E.T., Bett, K.L., Mcclung, A.M., Kauffmann, D. (2000). 'Instrumental assessment of cooked rice texture characteristics', A method for breeders. Cereal Chemistry. 77(4), pp. $512-517$.

Sangeetha, S.P., Balakrishnan, A., Devasenapathy, P. (2013). 'Influence of organic manures on yield and quality of rice (Oryza sativa L.) and black gram (Vigna mungo L.) in rice-black gram cropping sequence', American Journal of Plant Sciences, Scientific Research Publishing, Inc., 4(05), pp. 1151.

Srisawas, W., Jindal, V.K. (2007). 'Sensory evaluation of cooked rice about water-torice ratio and physicochemical properties', Journal of Texture Studies, 38(1), pp. $21-41$. 
Verma, D.K., Srivastav, P.P. (2017). 'Proximate composition, mineral content, and fatty acids analyses of aromatic and non-aromatic Indian rice'. Rice Science. 24(1), pp. $21-31$.

Weininger, J., Douglas, W.K.J., Truswell, A.S., Carpenter, K. (2018). 'Human nutrition', Encyclopedia Britannica, Inc. 98(2), pp. $115-120$.
Yu, T.R. (1991). 'Characteristics of soil acidity of paddy soils about rice growth', In: Wright R.J., Baligar, V.C. and Murrmann R.P. (Eds). Plant-soil interactions at low $\mathrm{pH}$. Development in Plant and Soil Sciences. Vol 45, pp. 107112. 